\title{
Adult neurogenic deficits in HIV-1 Tg26 transgenic mice
}

\author{
Raj Putatunda ${ }^{1,2}$, Yonggang Zhang ${ }^{1,2}$, Fang Li ${ }^{1,2}$, Xiao-Feng Yang ${ }^{1,4}$, Mary F Barbe ${ }^{3}$ and Wenhui Hu ${ }^{1,2^{*}}$ (D)
}

\begin{abstract}
Background: Even in the antiretroviral treatment (ART) era, HIV-1-infected patients suffer from milder forms of HIV1-associated neurocognitive disorders (HAND). While the viral proteins Tat and gp120 have been shown to individually inhibit the proliferation and neural differentiation of neural stem cells (NSCs), no studies have characterized the effects of all the combined viral proteins on adult neurogenesis.

Methods: The HIV-1 Tg26 transgenic mouse model was used due to its clinical relevance to ART-controlled HIV-1infected patients who lack active viral replication but suffer from continuous stress from the viral proteins. Quantitative RT-PCR analysis was performed to validate the expression of viral genes in the neurogenic zones. In vitro stemness and lineage differentiation assays were performed in cultured NSCs from HIV-1 Tg26 transgenic mice and their wild-type littermates. Hippocampal neurogenic lineage analysis was performed to determine potential changes in initial and late differentiation of NSCs in the subgranular zone (SGZ). Finally, fluorescent retroviral labeling of mature dentate granule neurons was performed to assess dendritic complexity and dendritic spine densities.
\end{abstract}

Results: Varying copy numbers of partial gag (p17), tat (unspliced and spliced variants), env (gp120), vpu, and nef transcripts were detected in the neurogenic zones of Tg26 mice. Significantly fewer primary neurospheres and a higher percentage of larger sized primary neurospheres were generated from Tg26 NSCs than from littermated wild-type mouse NSCs, implying that Tg26 mouse NSCs exhibit deficits in initial differentiation. In vitro differentiation assays revealed that Tg26 mouse NSCs have reduced neuronal differentiation and increased astrocytic differentiation. In the SGZs of Tg26 mice, significantly higher amounts of quiescent NSCs, as well as significantly lower levels of active NSCs, proliferating neural progenitor cells, and neuroblasts, were observed. Finally, newborn mature granule neurons in the dentate gyri of Tg26 mice had deficiencies in dendritic arborization, dendritic length, and dendritic spine density.

Conclusions: Both in vitro and in vivo studies demonstrate that HIV-1 Tg26 mice have early- and late-stage neurogenesis deficits, which could possibly contribute to the progression of HAND. Future therapies should be targeting this process to ameliorate, if not eliminate HAND-like symptoms in HIV-1-infected patients.

Keywords: HIV-1, HAND, Tg26 mouse, Neurogenesis, Neural stem cells, Stemness, Differentiation, Dendritic spine density

\section{Background}

Since the start of the antiretroviral treatment (ART) era, HIV-1-associated co-morbidities have manifested in the clinical population, most notably HIV-associated neurocognitive disorders (HAND), accelerated aging, cardiovascular diseases, and metabolic dysfunction [1]. HAND continues to affect over $50 \%$ of all HIV-1-infected

\footnotetext{
* Correspondence: whu@temple.edu

${ }^{1}$ Center for Metabolic Disease Research, Temple University Lewis Katz School of Medicine, 3500 N Broad Street, Philadelphia, PA 19140, USA

${ }^{2}$ Department of Pathology and Laboratory Medicine, Temple University Lewis Katz School of Medicine, 3500 N Broad Street, Philadelphia, PA 19140, USA Full list of author information is available at the end of the article
}

patients, even while undergoing ART treatment $[2,3]$. This disorder describes a specific spectrum of neurocognitive impairments such as asymptomatic neurocognitive impairment (ANI), mild neurocognitive disorder (MND), and HIV-associated dementia (HAD) [4]. Although the incidence of HAD has decreased due to ART, the incidence of MND continues to rise [5-8]. It is widely accepted that a key contributing factor of neuronal dysfunction in HIV-1 infection is attributed to the "Trojan Horse" mechanism of HIV-1 neuroinvasion via infected immune cells into the central nervous system (CNS) [9-11]. However, recent reports point to the

(c) The Author(s). 2018 Open Access This article is distributed under the terms of the Creative Commons Attribution 4.0 International License (http://creativecommons.org/licenses/by/4.0/), which permits unrestricted use, distribution, and 
possibility that chronic neuroinflammation from HIV-1 negatively impacts adult neurogenesis, thus contributing to the evolution of HAND $[2,12]$.

Neurogenesis describes the process in which neuronal and glial cells are generated from neural precursors that includes neural stem cells (NSCs) and neural progenitor cells (NPCs). This process takes place during prenatal development and throughout adult life $[13,14]$. In the context of adult neurogenesis, there are two main neurogenic niches: the subgranular zone (SGZ) in the dentate gyrus of the hippocampus and the subventricular zone (SVZ) lining the lateral ventricles [15-17]. In both neurogenic niches, slowly proliferating NSCs differentiate into rapidly proliferating NPCs, which then differentiate into neuroblasts and glioblasts that form neurons and glial cells respectively. Subsequently, these newborn neurons integrate into neural circuits to modulate olfactory processing and memory acquisition/maintenance [16].

Neurogenesis is important to study in the context of HAND, because HIV-1 virions have been found in the hippocampal formation of pediatric AIDS patients [18], and impaired neurogenesis has been observed in both HIV-1-infected patients and SIV-infected macaques $[19,20]$, as well as glial fibrillary acidic protein (GFAP)-driven gp120 transgenic mice [21-25] and GFAP-Tat transgenic mice [26, 27]. More importantly, NSCs have been shown to be targets of active HIV-1 infection [25, 27-32]. Additionally, well-known antiretroviral drugs such as AZT, efavirenz, and a tenofovir/emtricitabine/raltegravir cocktail inhibit NSC proliferation and differentiation in vitro and in vivo at pharmacologically relevant doses [33-35].

While previous studies hallmark the roles of active viral infection or viral protein production in neurogenic dysfunction $[22,24,25,27,31]$, the role of chronic/latent HIV-1 infection in the CNS remains poorly understood. Here, we utilized the HIV-1 Tg26 mouse model to evaluate adult neurogenesis. The $\operatorname{Tg} 26$ mouse line expresses seven of the nine HIV-1 viral proteins under the viral long terminal repeat (LTR) promoter [36-39]. Because the replication-deficient proviral HIV-1 DNA randomly integrates into the host genome and the viral transcripts are spontaneously driven by the LTRs, the $\operatorname{Tg} 26$ mice serve as an appropriate model for studying the long-term effects of viral proteins on the host. This model is clinically relevant to ART-controlled HIV-1-infected patients who lack active viral replication, but suffer from continuous stress from HIV-1 viral protein exposure. The aim of this study is to characterize the effects of the combined HIV-1 viral proteins on adult neurogenesis.

\section{Methods}

\section{Transgenic mice}

The Institutional Animal Care and Use Committee (IACUC) at Temple University (Philadelphia, PA) approved all procedures detailed in this study that required the use of vertebrate animals prior to initiating any experimental objectives. Additionally, all methods were performed in full compliance with Temple University's IACUC policies and the National Institutes of Health (NIH) ethical guidelines. Inbred HIV-1 Tg26 transgenic mice (Jackson Lab, \#022354) and their wild-type (WT) gender and age-matched littermates were utilized in this study. These mice harbor truncated HIV-1 NL4-3 genome with a 3.1-kb deletion in the Gag and Pol regions, rendering the latent provirus replication deficient [36]. The Tg26 mice were originally generated on the FV/B background and develop a well-characterized kidney disease. As a result, most mice are moribund between 2 and 6 months of age $[36,37]$. Since $\operatorname{Tg} 26$ mice on the C57BL/6J background do not develop kidney disease and have longer life expectancies [40-42], we generated $\operatorname{Tg} 26$ mice on a complete C57BL/6J background by backcrossing FVB/ $\mathrm{N}-\mathrm{Tg}(\mathrm{HIV}) 26 \mathrm{Aln} /$ PkltJ mice [36] with C57BL/6J mice (Jackson Lab, \#000664) for at least eight generations. Since Tg26 homozygous $(+/+)$ mice are runted and rarely survive to weaning [36], the $\operatorname{Tg} 26$ mice were maintained as heterozygotes $(+/-)$ throughout the study. Mice were utilized between 8 and 12 weeks old for all the proposed studies.

\section{Quantitative reverse transcription PCR (RT-qPCR)}

Total RNA was extracted from the brains of four $\operatorname{Tg} 26$ mice. Specifically, the SVZs, SGZs, olfactory bulbs, and kidneys were microdissected and stored in Trizol reagent (Thermo Fischer Scientific). The kidneys have been characterized to express proviral transcripts and served as an appropriate positive control for our studies $[36,37]$. Littermated WT mice were used as negative controls. The RNA was then purified with the Direct-zol RNA Miniprep Kit according to the manufacturer's instructions (Zymo Research Cat. \# R2052). Equal amounts (100 ng) of RNA from each sample was used for reverse transcription with the High Capacity cDNA Reverse Transcription Kit (Thermo Fischer Scientific Cat.\# 4368814), and 2 ng of cDNA was applied for qPCR using specific primers (Table 1, Fig. 1a) targeting partial gag (p17), tat (spliced and unspliced variants), env (gp120), vpu, and nef based on previously published reports $[43,44]$. Absolute quantification assays were performed using an HIV-1 pNL4-3 plasmid or reverse transcribed 2 or $4 \mathrm{~kb}$ HIV-1 cDNA fragments as the standards.

\section{Immunohistochemistry (IHC) and immunocytochemistry} (ICC)

The following antibodies were used in this study: chicken anti-GFAP (IHC and ICC 1:500, Aves Labs Cat\# GFAP, RRID:AB_2313547), Goat Sox2 (IHC and ICC 1:250, Santa 
Table 1 List of primers used for RT-qPCR and Tg26 mouse genotyping

\begin{tabular}{lll}
\hline Gene target & Direction & Sequence (5' to 3') \\
\hline Partial Gag (p17) & T760-forward & GGATAGATGTAAAAGACACCA \\
& T946-reverse & ACCTGGCTGTTGTTCCTGTGTC \\
Env (gp120) & T876-forward & CCGAAGGAATAGAAGAAGAAG \\
& T691-reverse & AGAGTAAGTCTCTCAAGCGG \\
Tat ${ }_{2}$ (spliced variant) & T1002-forward & TGGAAGCATCCAGGAAGTCAGCC \\
& T1003-reverse & TTCTTCTTCTATTCCTTCGGGCC \\
Tat ${ }_{1}$ (unspliced variant) & T1002-forward & TGGAAGCATCCAGGAAGTCAGCC \\
Nef & T1007-reverse & GAGAAGCTTGATGAGTCTGACTG \\
& F3.3-forward & CCGAAGGAATAGAAGAAGAAG \\
Vpu & R3.3-reverse & CTTGTAGCACCATCCAAAGG \\
PCR for mouse genotyping & T1002-forward & TGGAAGCATCCAGGAAGTCAGCC \\
& R1.3-reverse & GTGGTGGTGCTTCCTTCC \\
\hline
\end{tabular}

Cruz Biotechnology Cat\# sc-54517, RRID:AB_2195807), rabbit anti-Ki67 (IHC 1:500, Abcam Cat\# ab92353, RRID:AB_2049848), rabbit anti-eGFP (IHC 1:1000, Molecular Probes Cat\# A-6455, RRID:AB_221570), goat anti-doublecortin (DCX,1:500, Santa Cruz Biotechnology Cat\# sc-8066, RRID:AB_2088494), and rabbit anti- $\beta 3$-tubulin (Tuj1, ICC 1:1000, Sigma-Aldrich Cat\# T2200, RRID:AB_262133).

The IHC and ICC procedures have been conducted in a similar manner as described previously [45]. For ICC, cells were fixed in $4 \%$ paraformaldyhyde in phosphatebuffered saline (PBS) for $20 \mathrm{~min}$. After three consecutive PBS washes, the cells were permeabilized for $30 \mathrm{~min}$ with $0.5 \%$ Triton X-100 mixed with PBS. After permeabilization, the cells were blocked with $2 \%$ bovine serum albumin (BSA) dissolved in PBS with $0.1 \%$ Triton $\mathrm{X}-100$ for $1 \mathrm{~h}$. NSCs were then treated with primary antibodies diluted in blocking buffer overnight at $4{ }^{\circ} \mathrm{C}$. NSCs were washed three times with PBS and then treated with the appropriate Alexa fluorescent secondary antibodies at room temperature for $1 \mathrm{~h}$, followed by counterstaining with DAPI for $5 \mathrm{~min}$ and coverslipping with Fluoroshield (Sigma-Aldrich). Fluorescent confocal microscopy images were acquired and analyzed using the Leica SP8 confocal system.

For IHC, mice were euthanized with an overdose of avertin solution and transcardially perfused with $4 \%$ paraformaldehyde. The brains were dissected, postfixed overnight in the same fixative, and cryopreserved with buffered 30\% sucrose. A series of coronal sections of brain at $40 \mu \mathrm{m}$ thickness were cut cryostatically and stored at $-20{ }^{\circ} \mathrm{C}$. Then, standard multiple-labeled fluorescent IHC was performed. Briefly, the floating brain sections $(40 \mu \mathrm{m})$ were washed three times with $0.5 \%$ Triton X-100/tris-buffered saline (TBS) and blocked for
$30 \mathrm{~min}$ in blocking buffer containing 2\% BSA in TBS with $0.5 \%$ Triton $\mathrm{X}-100$. Then, primary antibodies were added and the sections were incubated overnight at $4{ }^{\circ} \mathrm{C}$. After three washes, the brain sections were treated with the corresponding Alexa fluorescent labeled secondary antibodies in blocking buffer for $1 \mathrm{~h}$ at room temperature. After washing and DAPI counterstaining (Sigma Aldrich Cat. \#D9542), brain sections were mounted onto glass microscope slides and then coverslipped with Fluoroshield (Sigma Aldrich Cat. \#F6182). Image acquisition and analysis was also performed with the Leica SP8 confocal system.

To assess in vivo hippocampal neurogenic dynamics, specific antibody combinations were used to label different cellular types. Generally, GFAP and Sox 2 co-localization is used to histologically mark NSCs, while Sox2 immunoreactivity only marks NPCs [46]. Additional Ki67 immunoreactivity would help distinguish quiescent NSCs from the actively dividing NSCs [47]. DCX is a microtubule-associated protein that is prominently expressed in neuroblasts, and becomes lost once the neuroblast terminally differentiates into a neuron, which usually expresses NeuN and $\beta 3$-tubulin. All these cell types during adult neurogenesis were quantified in an unbiased stereological manner as described previously $[24,27,46]$.

\section{In vitro NSC stemness and differentiation assay}

The isolation and culture of NSCs from 8- to 12-week-old WT or Tg26 mice were performed as described previously $[45,48]$. First, the mice were euthanized by cervical dislocation, and their brains were rapidly dissected and placed in dissection wash buffer (Hanks buffered salt solution containing $0.6 \%$ glucose, $10 \mathrm{mM}$ HEPES, $2 \mathrm{mM}$ L-glutamine, and $1 \%$ penicillin/streptomycin, all from Corning CellGro). Their SVZs were microdissected, placed in wash buffer, and 

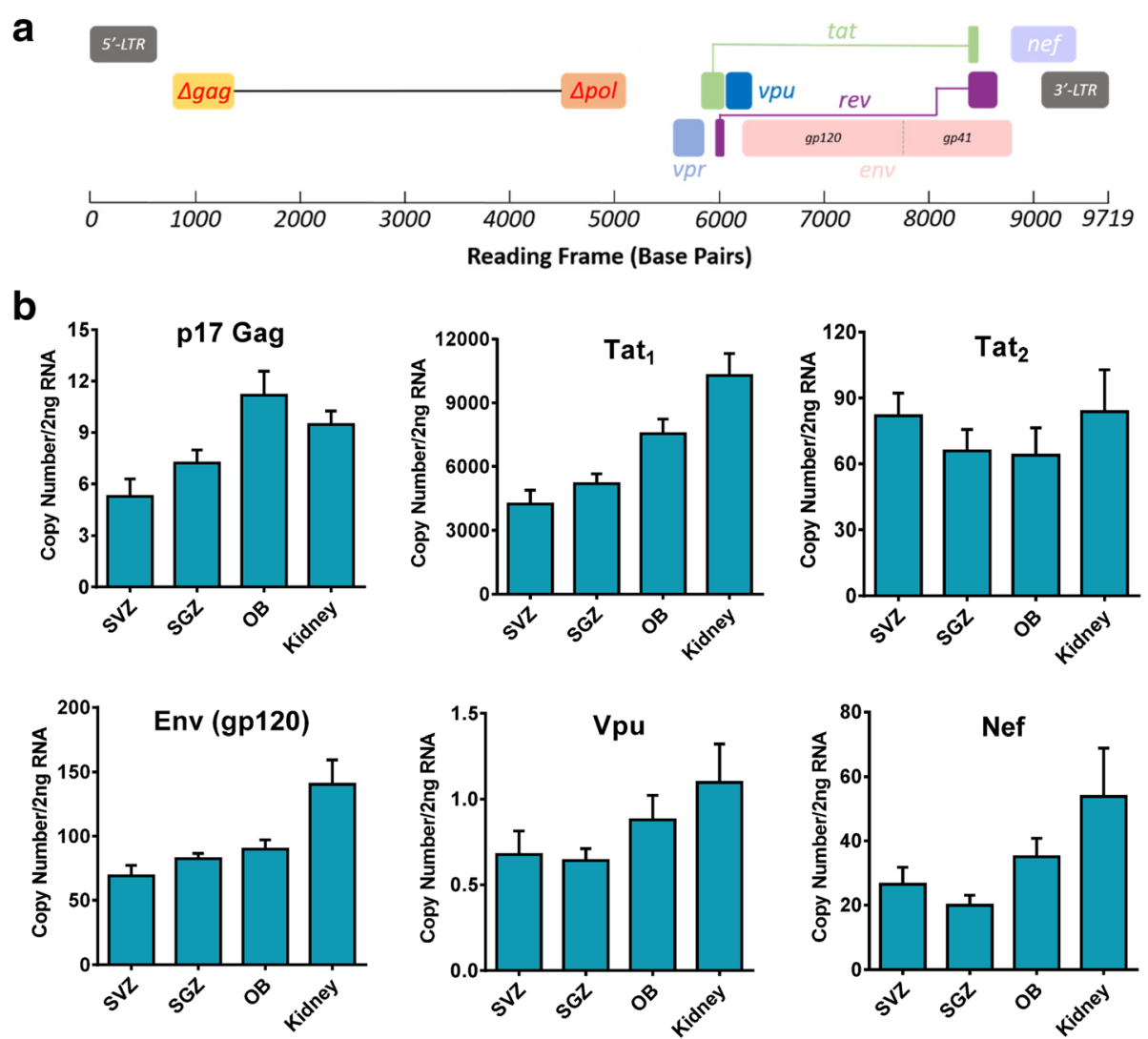

Fig. 1 HIV-1 Tg26 transgenic mice express viral mRNA in neurogenic regions. a Diagram of the truncated HIV-1 NL4-3 proviral genome in HIV-1 Tg26 mice, showing a deletion of $3.1 \mathrm{~kb}$ DNA spanning a majority of the Gag and Pol genes, and the predicted presence of seven viral gene transcripts. b RT-qPCR analysis of viral gene transcripts in neurogenic regions of HIV-1 Tg26 mice. Equal amount of RNA from the SVZs, SGZs, olfactory bulbs (OB), and kidneys of HIV-1 Tg26 mice was reverse transcribed, with 2 ng of the generated cDNA used for real-time PCR with primers covering $17 \mathrm{gag}$, tat, (unspliced variant), tat 2 (spliced variant), env (gp120), vpu, and nef. Samples were collected from four HIV-1 Tg26 mice (two males and two females), and reactions were run in triplicate. Values are expressed as mean \pm SEM

digested with Type IV Collagenase (Worthington Biochemical, Cat. \# CLS-4) and 0.05\% Trypsin (Thermo Fisher Scientific Cat. \# 25300054) diluted in wash buffer. After tissue digestion, the SVZ tissue was gently triturated with a P1000 pipette tip approximately 20 times until a homogenous cell suspension was achieved. The dissociated cells were then seeded in NSC culture media consisting of $0.2 \%$ heparin (Stem Cell Technologies Cat. \# 07980) (diluted 10,000×), $20 \mathrm{ng} / \mathrm{ml}$ epidermal growth factor (EGF) (Stem Cell Technologies Cat.\# 78016), $10 \mathrm{ng} / \mathrm{ml}$ basic fibroblast growth factor (bFGF) (Stem Cell Technologies Cat.\# 78003), 2 mM L-glutamine (Corning), and 1\% penicillin/streptomycin (Corning) in DMEM/F12 media (Corning). Primary neurospheres were grown in culture for 7 days, followed by microscopy and imaging to determine size and quantity of the neurospheres present.

The primary neurospheres were further digested with Accutase (Sigma) to obtain a single cell suspension for in vitro lineage differentiation studies as described previously $[45,48]$. Briefly, 20,000 cells were seeded in 4 well Matrigel-coated 8-well chamber slides per genotype in
NSC proliferation media. The next day, neural differentiation was induced by removal of bFGF and EGF $[45,49]$ and maintained for 5 days before fixation in $4 \%$ paraformaldyhyde. ICC was performed with antibodies against DCX (neuroblasts), $\beta 3$-tubulin (neurons), and GFAP (astrocytes). Confocal images were taken at five to eight fields per well, and the percentage of differentiated cells over DAPI-positive cells was quantified in a genotypeblinded manner.

\section{Retrovirus production and stereotaxic injection into the hippocampus}

Packaging of the eGFP-containing retrovirus was performed in GP2-293 cells (Clonetech Cat. \# 631458) in accordance with previously established protocols $[50,51]$. Briefly, $15 \mu \mathrm{g}$ of the pUX-eGFP vector (a gift from Dr. Shaoyu Ge at State University of New York) was co-transfected via the calcium phosphate method with $15 \mu \mathrm{g}$ of pVSVG per $100 \mathrm{~mm}$ dish when the GP2-293 cells were $70-80 \%$ confluent. At 48 and $72 \mathrm{~h}$ after transfection, the cell media, which contained infectious retroviral 
particles, was collected and pooled together for concentration via ultracentrifugation at 25,000 RPM for $2 \mathrm{~h}$ at $4{ }^{\circ} \mathrm{C}$. The viral pellet was resuspended in PBS and agitated overnight on a shaker in $4{ }^{\circ} \mathrm{C}$. Viral titering was performed on HEK293T cells, with titers ranging up to $1 \times 10^{8}$ colony-forming units (cfu)/ml.

Stereotaxic surgery was performed on 10-week-old mice. Before the injections, the mice were anesthetized with Avertin (Sigma Aldrich Cat. \#T48402-25G) (180 $\mu \mathrm{l} /$ $10 \mathrm{~g}$ body weight). Surgery was initiated when lack of tactile response was observed. The mice were mounted onto a stereotaxic frame, and the hair on the head was shaved to expose the scalp. After dissection of the scalp, four shallow holes were drilled into the skull using a dental drill ( $0.5 \mathrm{~mm}$ drill bit) at the following stereotaxic coordinates:

AP, $-2.0 \mathrm{~mm}$ from bregma; lateral, $\pm 1.5 \mathrm{~mm}$

AP, $-3.0 \mathrm{~mm}$ from bregma; lateral, $\pm 2.5 \mathrm{~mm}$

After the holes were drilled, $2 \mu \mathrm{l}$ of concentrated retrovirus was injected at each of these stereotaxic coordinates with a $10-\mu l$ Hamilton microsyringe:

AP, $-2.0 \mathrm{~mm}$ from bregma; lateral, $\pm .5 \mathrm{~mm}$; ventral, $2.0 \mathrm{~mm}$

AP, $-3.0 \mathrm{~mm}$ from bregma; lateral, $\pm 2.5 \mathrm{~mm}$; ventral, $-3.0 \mathrm{~mm}$

After the stereotaxic injections were completed, the wound was closed with sterile surgical sutures, and the mice were returned back to their cages until further analysis at 4 weeks after injection.

\section{Confocal imaging and Sholl/dendritic spine analysis of retroviral eGFP-labeled dentate granule neurons}

Imaging of eGFP-labeled dentate granule neurons for Sholl analysis and dendritic spine analysis was performed using a Leica SP8 confocal microscopy system. For Sholl analysis, images were taken at a $\times 63$ objective with a Z-stack thickness of $1.0 \mu \mathrm{m}$. For dendritic spine analysis, images were acquired with a $\times 63$ objective with a Z-stack thickness of $0.2 \mu \mathrm{m}$. For each granule neuron, three to four apical dendritic segments totaling approximately $200 \mu \mathrm{m}$ were used for dendritic spine analysis as described previously [52]. Neurolucida360 software (MBF Bioscience, RRID:SCR_001775) was used for Sholl and dendritic spine analysis, using maximum projection Z-stack images of the granule neurons or dendritic spines [53].

\section{Statistical analysis}

All statistical analysis was performed using GraphPad Prism 6.0. An unpaired two-tailed Student's $t$ test was performed between two groups of different treatments or genotypes. The $p$ value thresholds for statistical significance were set at $<0.05,<0.01$, and $<0.001$.

\section{Results}

HIV-1 Tg26 transgenic mice express viral mRNA in the neurogenic regions

Various transgenic animal models have been used for the study of HIV-1 [3]. While the HIV-1 transgenic rat has shown varying levels of proviral gene expression in the CNS [54], no studies to date have characterized the extent of proviral gene expression in the brains of HIV-1 Tg26 mice. To this end, absolute quantitative RT-PCR was performed using the primers targeting specific viral transcripts (Fig. 1a, Table 1) in the neurogenic regions. With this method, varying copy numbers of transcripts for partial gag (p17), tat (unspliced and spliced variants), env (gp120), vpu, and nef were detected in Tg26 mice (Fig. 1b), specifically in the SVZ and SGZ neurogenic regions. The unspliced tat 1 transcript showed the highest level of expression in all the neurogenic zones and the kidney. The env (gp120), the spliced tat2, and the nef transcripts showed the second highest levels of expression, though it is interesting to note that their expression levels were relatively similar. Finally, the $p 17$ gag transcript and the $v p u$ transcript showed the lowest levels of expression in the neurogenic zones and the kidney. However, $C_{t}$ values for the vif or vpr transcripts were not detected in the tested tissues or the kidney samples, most likely due to their relatively low expression levels. The PCR efficiency for vif and vpr was validated using the cDNA, which was reverse transcribed from the RNA of HIV-1 latent J-Lat cells. Interestingly, the expression levels of all the viral gene transcripts in the kidney were less than twofold higher than the expression levels in the neurogenic zones in the Tg26 mice with a pure C57BL/ 6J background.

\section{Neural stem cells (NSCs) from HIV-1 Tg26 transgenic mice exhibit in vitro NSC quiescence and neuronal lineage differentiation deficits}

To explore whether $\operatorname{Tg} 26$ transgenic mice exhibit early and late differentiation deficits, primary neurospheres were cultured from both Tg26 mice and WT littermated mice in accordance with previously established protocols [45]. The stemness assay [45] revealed significantly fewer number of primary neurospheres in $\operatorname{Tg} 26$ mice than that of littermated WT mice (Fig. 2a, b) $\left(t_{6}=5.836 ; p=0.0011\right)$. When the primary neurospheres were stratified by size (Fig. 2b), Tg26 mouse NSCs formed significantly less smaller sized neurospheres $(<75 \mu \mathrm{m}) \quad\left(t_{5}=4.049 ; p=\right.$ $0.0098)$, but significantly more large-sized neurospheres $(>150 \mu \mathrm{m})\left(t_{6}=2.829 ; p=0.0281\right)$. Since larger sized neurospheres typically contain more NSCs and smaller sized 
a
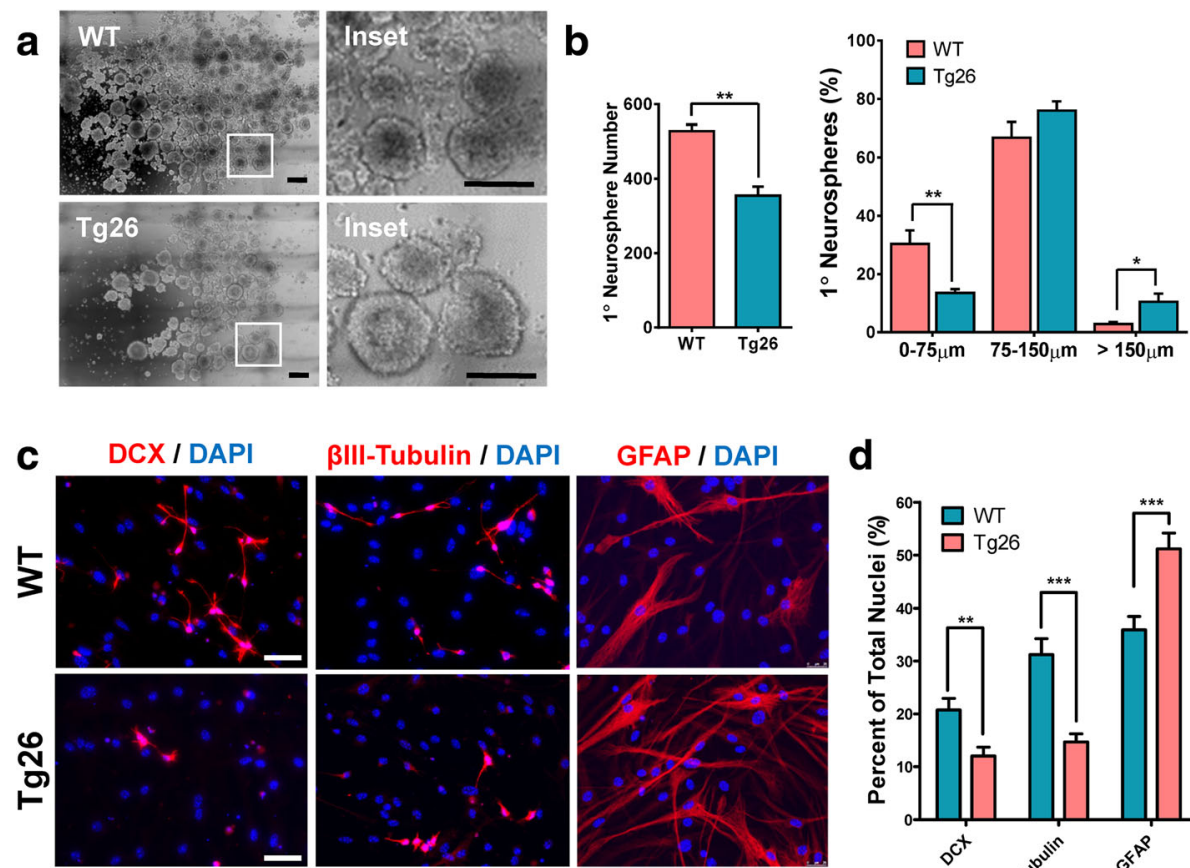

\section{d}

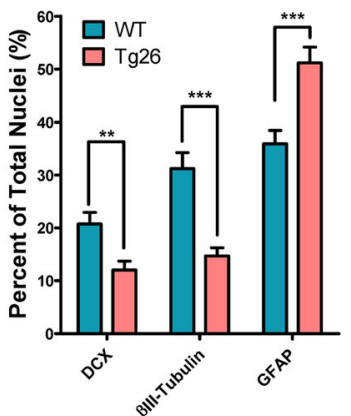

Fig. 2 In vitro stemness and neural lineage differentiation are impaired in HIV-1 Tg26 transgenic mice. a, b Fewer number of primary neurospheres but higher proportion of larger sized neurospheres in Tg26 mice. Representative tiled images of SVZ-derived primary neurospheres at 7 days in vitro are shown (a), and the number of the size stratified primary neurospheres was quantified using Image J software (b). Data is presented as the mean \pm SEM from four mice per genotype. c, d Reduced neuronal lineage differentiation but increased astroglial lineage differentiation in Tg26 mouse NSCs/ NPCs. Dissociated NSCs/NPCs from primary neurospheres were differentiated for 5 days followed by immunocytochemistry with cell lineage-specific antibodies to assess for neuroblast (DCX) and neuronal ( 33 tubulin) differentiation, and astrocytic (GFAP) formation (c). Tg26 mouse NSCs were unable to form as many neuroblasts or neurons as wild-type (WT) mouse NSCs, but instead formed more astrocytes (d). The quantitative differentiation data is presented as the Mean \pm SEM from 4 mice ( 2 males and 2 females per genotype), with five to eight random fields per mouse for each cellular marker. Scale bar in a, $300 \mu \mathrm{m}$; inset, $150 \mu \mathrm{m}$. Scale bar in c $50 \mu \mathrm{m} .{ }^{*} p<0.05,{ }^{* *} p<0.01,{ }^{* * *} p<0.001$

neurospheres contain more NPCs [45, 48, 54, 55], these results suggest that $\mathrm{Tg} 26 \mathrm{NSCs}$ have significantly increased quiescence, implying that Tg26 mouse NSCs exhibit deficits in initial differentiation of NSCs to NPCs.

After the initial differentiation of NSCs to NPCs, the differentiation of NPCs to neuroblasts and finally the immature/mature neural cells continues throughout the middle/late stages of adult neurogenesis [16]. To explore whether the chronic stress induced by HIV-1 viral proteins affects neural lineage differentiation, multi-labeled ICC analysis of cultured differentiated NSCs was performed. As shown in Fig. 2c, d, Tg26 NSCs were unable to form as many neuroblasts $\left(t_{48}=3.222 ; p=0.0023\right)$ and neurons $\left(t_{58}=6.4989 ; p<0.0001\right)$ as WT NSCs. However, Tg26 NSCs had an increased incidence of astrocyte formation $\left(t_{58}=3.889 ; p=0.0003\right)$. These results show that Tg26 NSCs exhibit hampered neuronal differentiation and aberrant astrocytic differentiation.
HIV-1 Tg26 mice exhibit hippocampal neurogenic deficits in vivo

To validate the in vitro findings that $\operatorname{Tg} 26$ NSCs exhibit stemness and neuronal differentiation impairments, multi-labeled fluorescent IHC with cell-specific markers and confocal imaging analysis (Fig. 3a, b) were performed in serial brain sections from WT and Tg26 mice. Stereological quantification (Fig. 3c) showed that the SGZs of Tg26 mice had significantly higher numbers of quiescent NSCs $\left(t_{8}=2.447 ; p=0.0401\right)$ and significantly lower levels of NSC proliferation $\left(t_{9}=3.523 ; p=0.0065\right)$. Additionally, Tg26 mouse SGZs showed fewer numbers of NPCs than WT mouse SGZs $\left(t_{7}=4.04 ; p=0.0049\right)$. Finally, Tg26 mouse SGZs had lower neuroblast formation (Fig. 3d, e), as depicted by significantly fewer numbers of DCX immunostained cells in the SGZ $\left(t_{8}=3.061 ; p=0.0156\right)$. Altogether, these studies suggest that Tg26 mice have significantly increased NSC quiescence and impaired initial differentiation of NSCs into NPCs as well as decreased neuronal lineage differentiation in vivo. This further 

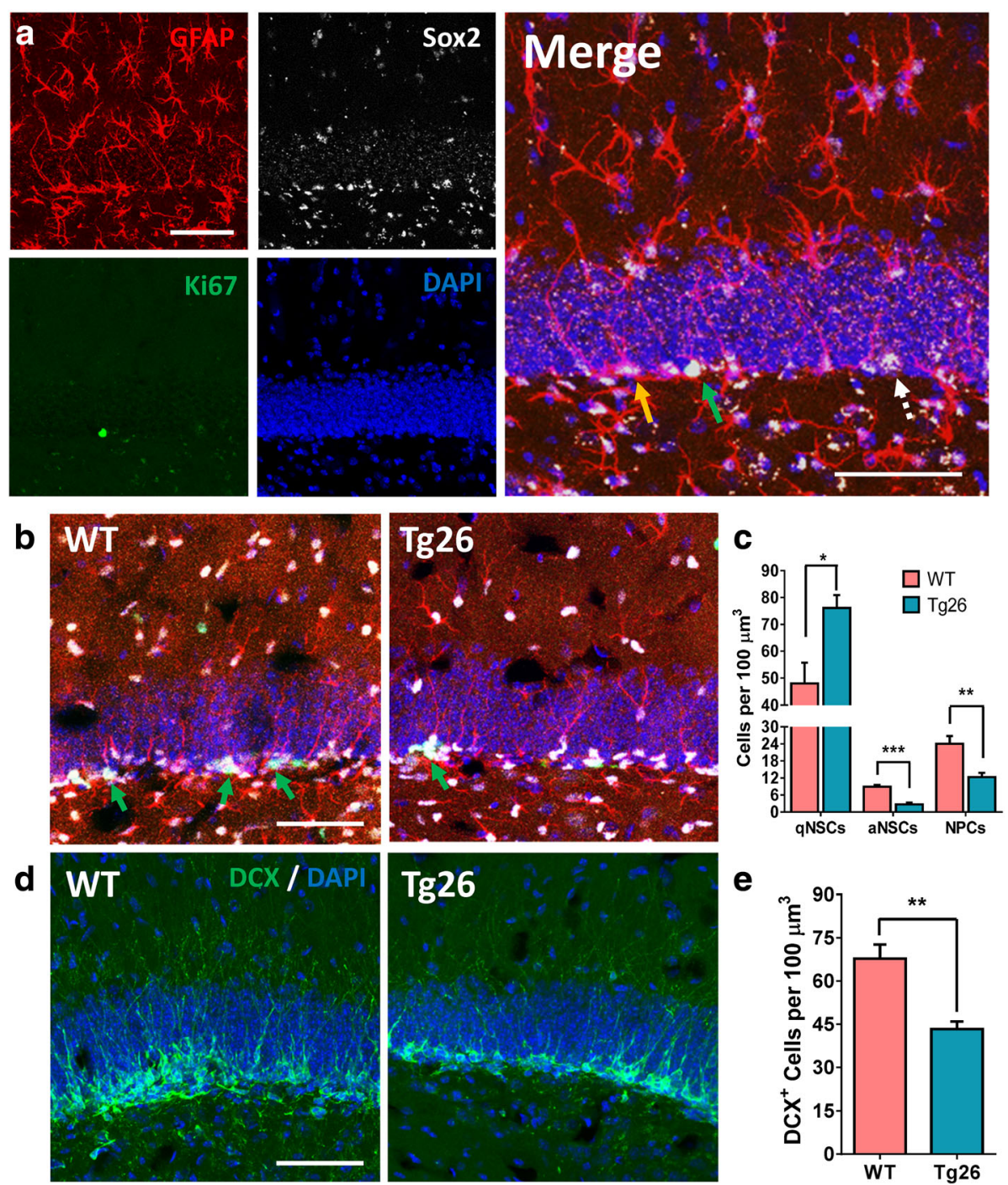

Fig. 3 Tg26 mice exhibit hippocampal neurogenesis deficits. a Representative confocal image showing quiescent NSCs (qNSCs, orange arrow, $\mathrm{GFAP}^{+} / \mathrm{Sox} 2^{+} / \mathrm{Ki} 67^{-}$), active NSCs (aNSCs, green arrow, GFAP $/$Sox $2^{+} / \mathrm{Ki} 67^{+}$), and NPCs (dashed arrow, GFAP $/$Sox2 $2^{+}$) in the SGZ. $\mathbf{b}$ Comparative SGZ images from WT and littermated Tg26 mice showing less aNSCs (green arrows) in Tg26 mice. c Stereological quantification revealed significantly increased numbers of qNSCs, decreased numbers of aNSCs, and decreased numbers of NPCs in Tg26 mouse SGZs. d Representative confocal images showing DCX-positive neuroblasts in WT and Tg26 SGZs. e Stereological quantification revealing less neuroblast formation in Tg26 mice. Data in c and e represent the mean \pm SEM from five to six mice per genotype (all females). Scale bars in $\mathbf{a}, \mathbf{b}$, and $\mathbf{d}, 50 \mu \mathrm{m} .{ }^{*} p<0.05$ and ${ }^{* *} p<0.01$ indicate statistical changes compared with the corresponding WT SGZ

confirms the in vitro results from the primary neurosphere assays and the in vitro lineage differentiation assays.

Newborn dentate granule neurons in HIV-1 Tg26 mice exhibit dendritic arborization deficits, decreased dendritic length, and decreased dendritic spine density

Both the in vitro and in vivo studies, as described above, have shown that HIV-1 transgenic viral proteins significantly perturbed NSC initial differentiation and neuroblast/neuronal linage differentiation during adult neurogenesis. Next, experiments were performed to determine whether chronic stress from HIV-1 viral proteins in $\operatorname{Tg} 26$ mice had effects on late-stage neuronal maturation. Therefore, the maturation of newborn granule neurons in the dentate gyrus was analyzed using a well-established retroviral eGFP labeling technology $[24,50,51]$. Here, actively dividing cells (i.e., active NSCs, proliferating NPCs, and a few dividing neuroblasts) were instantly labeled with the eGFP reporter after stereotaxic injection of the retrovirus into the dentate gyrus. The fate of the labeled cells was mapped at different times after injection as described previously $[24,50,51]$. Studies have shown that 
maturation of newborn granule neurons from SGZ NSCs can be viewed by eGFP IHC and confocal image analysis approximately 4 weeks after retroviral injection in mice [50]. To identify any potential effects of chronic HIV-1 viral protein stress on dendritic arborization and spinogenesis during neuronal maturation [50], Sholl analysis on eGFP-labeled granule neurons in SGZ of WT and Tg26 mice at 4 weeks after retroviral injection into the dentate gyrus was performed using Neurolucida360 software (Fig. 4a). The eGFP-labeled newborn neurons in Tg26 mice exhibited significantly lower levels of dendritic arborization and complexity (Fig. $4 \mathrm{~b})$ at $20 \mu \mathrm{m}\left(t_{56}=\right.$ $2.557 ; p=0.0133), \quad 30 \mu \mathrm{m} \quad\left(t_{56}=3.116 ; p=0.0029\right)$, $40 \mu \mathrm{m}\left(t_{64}=2.753 ; p=0.0077\right), 50 \mu \mathrm{m}\left(t_{56}=2.590 ; p=\right.$ $0.0122), 60 \mu \mathrm{m}\left(t_{56}=2.115 ; p=0.0389\right), 70 \mu \mathrm{m}\left(t_{56}=\right.$ $2.401 ; p=0.0197), 160 \mu \mathrm{m} \quad\left(t_{31}=2.492 ; p=0.0182\right)$, and $170 \mu \mathrm{m}\left(t_{27}=2.411 ; p=0.0230\right)$ away from the cell soma. This decrease in dendritic complexity also correlated with $\operatorname{Tg} 26$ granule neurons having a lower dendritic length (Fig. 4c) $\left(t_{48}=2.035 ; p=0.0474\right)$. However, total dendritic surface area and dendritic volume remained unchanged (Fig. $4 \mathrm{~d}$, e). In addition to dendritic arborization deficits, several studies have shown that HIV-1-infected patients exhibit synaptodendritic damage, even while on ART [56, 57]. To examine whether $\operatorname{Tg} 26$ mouse dentate granule neurons have any changes in dendritic spine integrity, dendritic spine density analysis was conducted to assess any differences in total spine density, thin spine density, stubby spine density, and mushroom spine density (Fig. 5a). The eGFP-labeled granule neurons from HIV-1 $\operatorname{Tg} 26$ mice had significantly less apical dendritic spine densities $\left(t_{43}=5.681 ; p<0.0001\right)$ compared to that from WT mice (Fig. 5b). Dendritic spines come in a variety of shapes and sizes, with the more common classifications being designated as thin spines, stubby spines, and mushroom-shaped spines [53]. Quantification of these specific spine types revealed that $\operatorname{Tg} 26$ granule neurons had a significantly lower thin spine density (Fig. 5c) $\left(t_{40}=2.047 ; p=\right.$ $0.0473)$ and stubby spine density (Fig. 5 d $)\left(t_{41}=2.884\right.$; $p=0.0062$ ). However, quantification of mushroom spine density revealed that there were no differences between WT and $\operatorname{Tg} 26$ granule neurons (Fig. 5e). This data suggests that low-level chronic HIV-1 expression induces synaptodendritic damage in a manner similarly observed in HIV-1-infected patients [5].
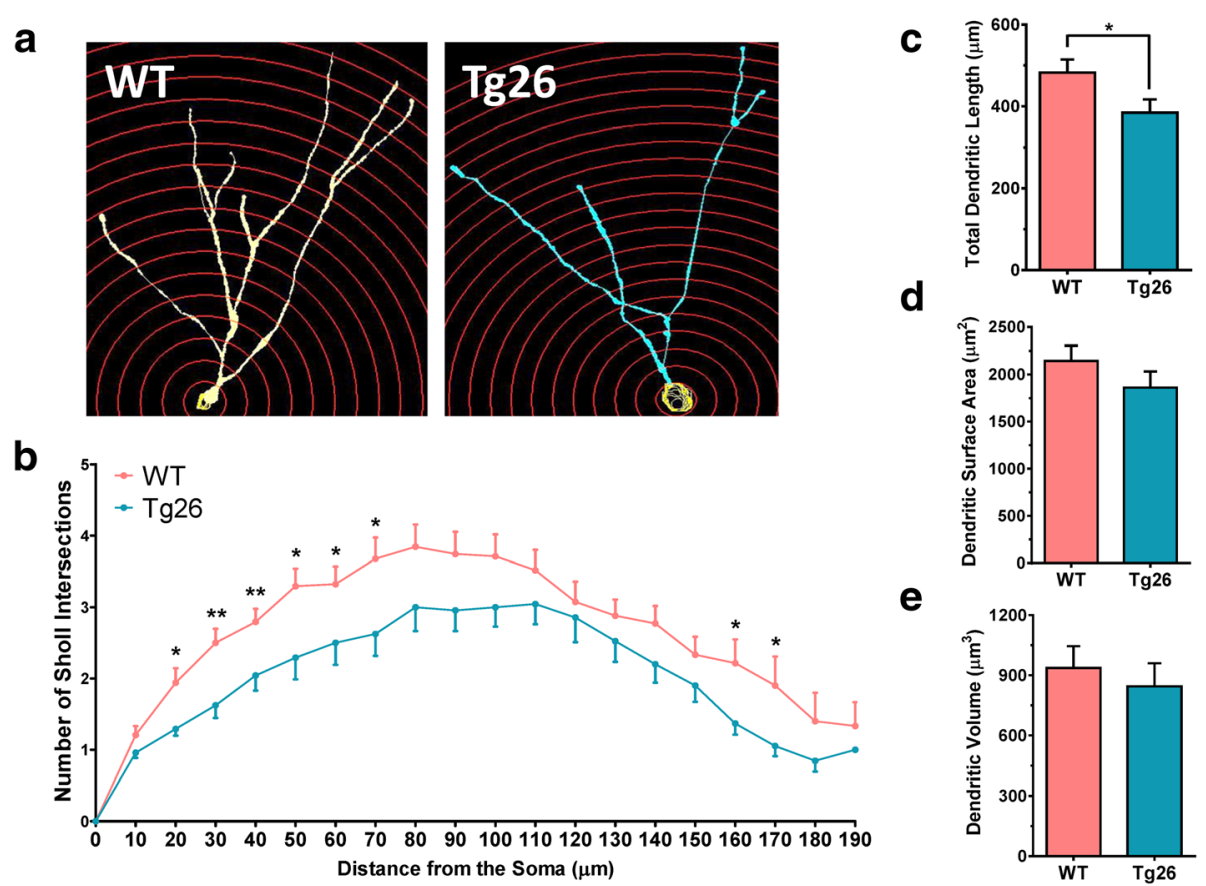

Fig. 4 Newborn dentate granule neurons in Tg26 mice have lower dendritic complexity and length. a Representative retroviral eGFP-labeled dentate granule neurons from WT and Tg26 mice with the Sholl analysis. Each Sholl circle increases in diameter by $10 \mu \mathrm{m}$ from the cell soma. $\mathbf{b}$ Quantitative data of Sholl intersections. c-e Retroviral eGFP-labeled dentate granule neurons in WT and Tg26 mice were also assessed for total dendritic length (c), dendritic surface area (d), and dendritic volume (e). Data is presented as the mean \pm SEM from four mice (three males and one female per genotype), with six to eight granule neurons being analyzed per mouse. ${ }^{*} p<0.05$ and ${ }^{* *} p<0.01$ indicate statistical changes compared with corresponding WT granule neuron 
a

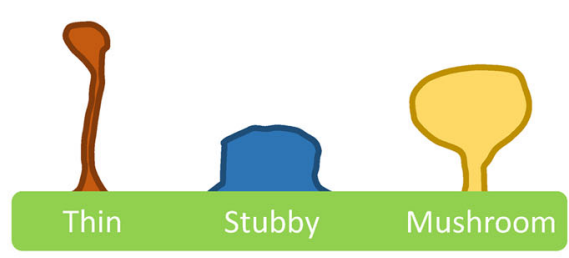

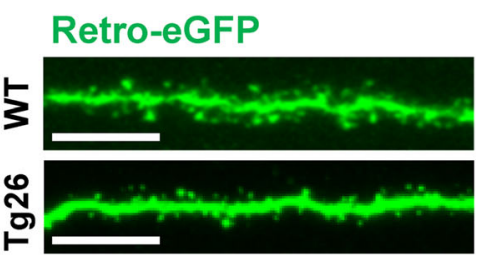

d

b

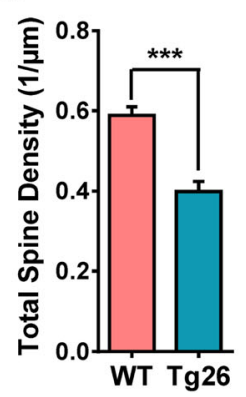

C

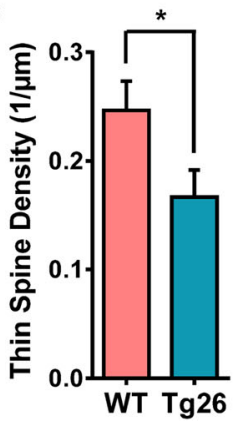

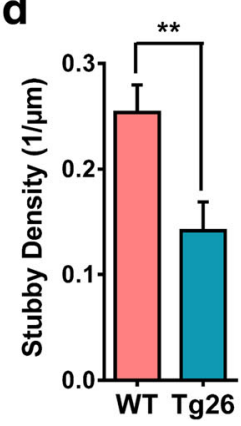

e

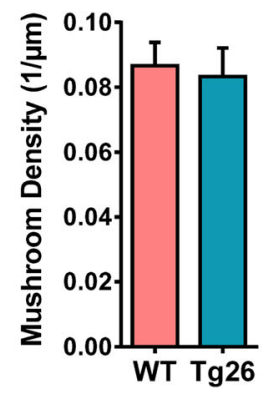

Fig. 5 Newborn dentate granule neurons in Tg26 mice harbor decreased apical dendritic spine density. a Diagram of dendritic spine types and representative images of retroviral eGFP-labeled apical dendritic arbors from WT and Tg26 granule neurons. b-e Quantitative analysis of total dendritic density as well as densities for specific spine types. Data is presented as the mean \pm SEM from four mice (three males and one female per genotype), with at least $200 \mu \mathrm{m}$ of apical dendritic arbors from six to eight granule neurons being analyzed per mouse. Scale bar in a, $6.25 \mu \mathrm{m} .{ }^{*} p<0.05,{ }^{* *} p<0.01$, and ${ }^{* * *} p<0.001$ indicate statistical changes compared with the corresponding WT dendritic arbor

\section{Discussion}

In the ART era, HIV-1 infection continues to elicit mild to moderate forms of HAND, more notably ANI and MND [5, 6]. Many mechanisms have been characterized that explain some of the pathogenesis underlying ANI/ MND, but recently, compromised adult neurogenic changes have been proposed as a newer mechanism for HIV-induced CNS injury [2, 3, 27, 31]. The salient findings of this study include (1) varying levels of HIV-1 proviral transcripts in the neurogenic zones of HIV-1 Tg26 mice, (2) deficits in initial NSC differentiation into NPCs in vitro and in vivo, (3) decreased neuronal lineage differentiation in vitro and in vivo, and (4) impairment of neuronal maturation and spinogenesis in newborn dentate granule neurons. These findings solidify the HIV-1 Tg26 mouse model as an appropriate approach to study the milder forms of HAND, which are clinically relevant to the HIV-1 latently infected population under ART today $[6,58]$.

Several pioneering studies have shown mosaic levels of HIV-1 proviral expression in peripheral organs such as the spleen, thymus, kidney, and muscle of $\operatorname{Tg} 26$ mice $[36,37,59]$. However, no previous studies have assessed viral gene expression levels in Tg26 mouse brains. To our knowledge, we are the first group to show the presence of the unspliced and spliced transcripts of HIV-1 viral genes not just in the brain, but specifically in different neurogenic niches. Our RT-PCR analysis revealed mosaic levels of p17 Gag, Tat (unspliced and spliced variants), Env (gp120), Vpu, and Nef transcripts in the different neurogenic zones. These mosaic levels of proviral gene transcript expression are consistent with previous reports in HIV-1 transgenic rats using the same truncated pNL4-3 construct with all the transcripts driven by the HIV-1 5'-LTR promoter [54]. Interestingly, the unspliced Tat1 transcript showed a dramatically higher expression level than the spliced Tat 2 transcript and other viral transcripts, implying that Tat 1 might be the major contributor to CNS neurotoxicity [60-62]. Due to replication deficiency, the expression of these viral transcripts is relatively lower but constitutively persistent, implicating its clinical relevance to chronic HIV-1 infection in the ART era. The presence of HIV-1 viral transcripts in neurogenic zones also supports an earlier clinical finding by in situ hybridization in the SVZ and SGZ of a post-mortem patient with severe NeuroAIDS, showing that HIV-1 RNA transcripts localized to the neurogenic zones [18]. Further analysis using more sensitive technologies such as RNA/DNAscope $[63,64]$ and barcoded single-cell sequencing $[65,66]$ are warranted to distinguish the cellular distribution of HIV-1 viral transcripts in the neurogenic zones.

Most cases of HAND consist of subtle or milder forms of neurocognitive deficits. Since neurogenic defects have been shown to contribute to developing many subtle neurocognitive changes after CNS injury or neurodegenerative diseases $[67,68]$, it has been hypothesized that neurogenic impairment may contribute to the more subtle forms of HAND. This neurogenic impairment by HIV-1 single viral proteins has been demonstrated by several previous studies 
using in vitro cell cultures $[25,28,31]$ and in vivo transgenic animal models $[22,24,27,56,69]$. For example, treating cultured NSCs/NPCs with Tat has been shown to inhibit NSC proliferation and differentiation through attenuation of the ERK pathway [70] and the p38-MAPK pathway [71] or through activation of the Notch pathway [27]. Additionally, treating NSCs/NPCs with gp120 suppresses NSC proliferation via activation of p38 MAPK pathway [25]. In this study, we performed a more comprehensive evaluation of impaired neurogenesis at both the in vitro and in vivo levels using a clinically relevant HIV-1 transgenic mouse model that harbors seven of nine HIV-1 viral genes. Our in vitro NSC stemness assays revealed a significantly diminished NSC pool in $\mathrm{Tg} 26$ mice compared to their WT littermates, as assessed by the reduced number of the primary neurospheres generated. Additionally, we found that chronic HIV-1 viral protein stress increased the formation of larger sized primary neurospheres, implying the impairment of initial differentiation of NSCs into NPCs. Primary neurospheres contain a mixed population of de novo NSCs and NPCs [45, 48], and larger sized neurospheres represent the existence of the tri-potential, self-renewing NSCs $[55,72]$. These in vitro findings were validated in vivo, as Tg26 mouse SGZs had a higher level of quiescent NSCs, while having a diminished proliferating NSC population as well as a lower NPC pool. This increased NSC quiescence due to the hampered initial activation and differentiation into NPCs is consistent with previous reports on cultured NSCs treated with Tat and other viral proteins $[70,71,73-75]$ and using in vivo animal models $[20,25,73,74,76]$.

NSCs/NPCs terminally differentiate into neurons and glial cells. This lineage differentiation process is regulated by a series of environmental niche factors. Inflammatory mediators such as cytokines and chemokines have been widely shown to regulate this tri-potential lineage differentiation pattern in varying ways. The direct effects of chronic HIV-1 infection or viral proteins on NSC lineage differentiation have yet to be comprehensively understood. Our in vitro and in vivo neural lineage differentiation studies have shown that $\operatorname{Tg} 26$ NSCs have a decreased affinity towards neuronal lineage differentiation, but exhibit increased astroglial lineage differentiation. Similar effects have been observed in cultured NSCs/NPCs treated with Tat $[70,77]$ or direct HIV-1 infection [76], as well as in mice with HIV-1 encephalitis [78], doxycycline-inducible GFAP-Tat transgenic mice [27], and GFAP-gp120 mice [24, 25, 79]. However, a recent in vitro study has shown that active HIV-1 infection of human NSCs promotes both neuronal and astroglial lineage differentiation, when compared to uninfected human NSCs [31]. One possible explanation could be intrinsic mechanistic difference between various HIV-1 strains: the CCR5-tropic HIV-1 BaL viral strain in previous study [31] vs the CXCR4-tropic NL4-3 strain in $\operatorname{Tg} 26$ mice. CCR5-tropic viruses represent the predominant viral population right after initial infection, but CXCR4 tropic viruses are associated with progressive CNS injury [80, 81]. In the clinical setting, CXCR4 tropic viruses may contribute more to the milder forms of HAND than CCR5 tropic viruses [3], which would make our in vivo HIV-1 Tg26 mouse model more clinically relevant. Another explanation may be the type of infection being performed: active infection vs. low-level chronic/latent infection. The supernatant from HIV-infected peripheral blood mononuclear cells may induce a more robust and confounding effect on NSC differentiation due to the combination of active virial particles, HIV-1 viral proteins, growth factors, and inflammatory mediators secreted by the infected cells [31].

Adult neurogenesis is a process that describes the generation of neural lineage cells from NSCs and NPCs. However, it is important to recognize the neuronal maturation and synaptic integration into this process. As of now, no studies have examined the effects of chronic HIV-1 infection and proviral protein stress on newborn neuronal formation and maturation. Retroviral eGFP labeling of newborn granule neurons in the dentate gyrus revealed that $\operatorname{Tg} 26$ mouse granule neurons have significantly decreased dendritic morphology, decreased total dendritic length, and decreased dendritic spine densities. These findings are notable, as these are the first to implicate the combined HIV-1 viral proteins in dendritic arborization deficits in newborn dentate granule neurons. Our observed decrease in dendritic spine density in dentate granule neurons is consistent with a previous study analyzing dendritic spine damage in layer II/III pyramidal prefrontal cortical neurons of both HIV-1 transgenic rats and gp120 infused rats [52], as well as aberrant dendritic development of newborn neurons in GFAP-gp120 transgenic mice [24]. Our Neurolucida360 studies further elaborated on the detrimental effects on various types of dendritic spines (thin, stubby, or mushroom spines) instead of only total dendritic spine density [52]. Additionally, our Sholl analysis identified dendritic morphological deficits of newborn hippocampal dentate granule neurons in $\operatorname{Tg} 26$ mice, while no differences in pyramidal cortical neuron dendritic length or branching were observed in HIV-1 transgenic rats [52]. This abnormal dendritic arborization in HIV-1 Tg26 mouse dentate granule neurons also supports a previous study using similar retroviral labeling technology of newborn dentate granule neurons in GFAP-gp120 mice [24]. However, further electrophysiological and circuit tracing experiments are needed to assess any functional differences in the newborn matured granule neurons between WT and Tg26 mice. Additionally, the molecular mechanisms behind the abnormal dendritic spine density in HIV-1 Tg26 mice remain to be determined. 


\section{Conclusions}

Our in vitro and in vivo studies demonstrate that HIV-1 Tg26 transgenic mice manifest early-state and late-stage neurogenic deficits, when compared to their WT littermates. Additionally, these neurogenic deficits lead to deficient dentate granule neuron morphology as well as decreased dendritic spine densities. These neurogenic deficits may possibly play a role modulating learning and memory function in these mice, which is an interesting topic for further investigation.

\begin{abstract}
Abbreviations
ANI: Asymptomatic neurocognitive impairment; ART: Antiretroviral treatment; bFGF: Basic fibroblast growth factor; CNS: Central nervous system; DCX: Doublecortin; EGF: Epidermal growth factor; eGFP: Enhanced green fluorescent protein; GFAP: Glial fibrillary acidic protein; HAD: HIV-associated dementia; HAND: HIV-associated neurocognitive disorders; HIV: Human immunodeficiency virus; ICC: Immunocytochemistry;

IHC: Immunohistochemistry; LTR: Long terminal repeat; MND: Mild neurocognitive disorder; NPCs: Neural progenitor cells; NSCs: Neural stem cells; PBS: Phosphate-buffered saline; RT-PCR: Reverse transcriptionpolymerase chain reaction; SGZ: Subgranular zone; SVZ: Subventricular zone; TBS: Tris-buffered saline; TG: Transgenic; WT: Wild-type
\end{abstract}

\section{Acknowledgements}

We thank Dr. Shaoyu Ge at State University of New York at Stony Brook for the retroviral pUX-eGFP vector and critical comment.

\section{Funding}

This work was supported by the National Institutes of Health (R01DK075964 to W.H. and T32MH079785 to R.P).

\section{Availability of data and materials}

The data and research materials are available from the corresponding authors upon a reasonable written request.

\section{Authors' contributions}

$R P, Y Z$, and WH designed the research. RP, YZ, and FL performed the cell culture, immunohistochemistry, confocal imaging, and quantitative analysis. RP and FL performed RT-qPCR analysis. RP, WH, and XFY analyzed the data and prepared figures. RP, MFB, and WH wrote and edited the manuscript. All authors read and approved the final manuscript.

\section{Ethics approval}

All procedures for animal usage were complied with the guidelines of the National Institutes of Health and approved by the Institutional Animal Care and Use Committee (IACUC) at Temple University (approval number 4324).

\section{Consent for publication}

Not applicable.

\section{Competing interests}

The authors declare that they have no competing interests.

\section{Publisher's Note}

Springer Nature remains neutral with regard to jurisdictional claims in published maps and institutional affiliations.

\section{Author details}

${ }^{1}$ Center for Metabolic Disease Research, Temple University Lewis Katz School of Medicine, 3500 N Broad Street, Philadelphia, PA 19140, USA. ²Department of Pathology and Laboratory Medicine, Temple University Lewis Katz School of Medicine, 3500 N Broad Street, Philadelphia, PA 19140, USA. ${ }^{3}$ Department of Anatomy and Cell Biology, Temple University Lewis Katz School of Medicine, 3500 N Broad Street, Philadelphia, PA 19140, USA. ${ }^{4}$ Department of Pharmacology, Temple University Lewis Katz School of Medicine, $3500 \mathrm{~N}$ Broad Street, Philadelphia, PA 19140, USA.
Received: 28 May 2018 Accepted: 24 September 2018

Published online: 12 October 2018

\section{References}

1. Rodriguez-Penney AT, ludicello JE, Riggs PK, Doyle K, Ellis RJ, Letendre SL, Grant I, Woods SP, Group HIVNRPH. Co-morbidities in persons infected with HIV: increased burden with older age and negative effects on health-related quality of life. AIDS Patient Care STDs. 2013;27:5-16.

2. Ferrell D, Giunta B. The impact of HIV-1 on neurogenesis: implications for HAND. Cell Mol Life Sci. 2014;71:4387-92.

3. Saylor D, Dickens AM, Sacktor N, Haughey N, Slusher B, Pletnikov M, Mankowski JL, Brown A, Volsky DJ, McArthur JC. HIV-associated neurocognitive disorder--pathogenesis and prospects for treatment. Nat Rev Neurol. 2016;12:234-48.

4. Antinori A, Arendt G, Becker JT, Brew BJ, Byrd DA, Cherner M, Clifford DB, Cinque P, Epstein LG, Goodkin K, et al. Updated research nosology for HIVassociated neurocognitive disorders. Neurology. 2007;69:1789-99.

5. Ellis RJ, Deutsch R, Heaton RK, Marcotte TD, McCutchan JA, Nelson JA, Abramson I, Thal LJ, Atkinson JH, Wallace MR, Grant I. Neurocognitive impairment is an independent risk factor for death in HIV infection. San Diego HIV Neurobehavioral Research Center Group. Arch Neurol. 1997; 54:416-24.

6. Heaton RK, Clifford DB, Franklin DR Jr, Woods SP, Ake C, Vaida F, Ellis RJ, Letendre SL, Marcotte TD, Atkinson JH, et al. HIV-associated neurocognitive disorders persist in the era of potent antiretroviral therapy: CHARTER study. Neurology. 2010:75:2087-96.

7. Kaul M, Garden GA, Lipton SA. Pathways to neuronal injury and apoptosis in HIV-associated dementia. Nature. 2001;410:988-94.

8. Kaul M, Zheng J, Okamoto S, Gendelman HE, Lipton SA. HIV-1 infection and AIDS: consequences for the central nervous system. Cell Death Differ. 2005; 12(Suppl 1):878-92.

9. Gonzalez-Scarano F, Martin-Garcia J. The neuropathogenesis of AIDS. Nat Rev Immunol. 2005:5:69-81.

10. Liu NQ, Lossinsky AS, Popik W, Li X, Gujuluva C, Kriederman B, Roberts J, Pushkarsky T, Bukrinsky M, Witte M, et al. Human immunodeficiency virus type 1 enters brain microvascular endothelia by macropinocytosis dependent on lipid rafts and the mitogen-activated protein kinase signaling pathway. J Virol. 2002;76:6689-700.

11. Williams KC, Hickey WF. Central nervous system damage, monocytes and macrophages, and neurological disorders in AIDS. Annu Rev Neurosci. 2002; 25:537-62.

12. Kaul M. HIV's double strike at the brain: neuronal toxicity and compromised neurogenesis. Front Biosci. 2008;13:2484-94.

13. Duan X, Kang E, Liu CY, Ming GL, Song H. Development of neural stem cell in the adult brain. Curr Opin Neurobiol. 2008;18:108-15.

14. Ming GL, Song H. Adult neurogenesis in the mammalian central nervous system. Annu Rev Neurosci. 2005;28:223-50.

15. Ihrie RA, Alvarez-Buylla A. Lake-front property: a unique germinal niche by the lateral ventricles of the adult brain. Neuron. 2011;70:674-86.

16. Ming GL, Song $\mathrm{H}$. Adult neurogenesis in the mammalian brain: significant answers and significant questions. Neuron. 2011;70:687-702.

17. Riquelme PA, Drapeau E, Doetsch F. Brain micro-ecologies: neural stem cell niches in the adult mammalian brain. Philos Trans R Soc Lond Ser B Biol Sci. 2008;363:123-37.

18. Schwartz L, Civitello L, Dunn-Pirio A, Ryschkewitsch S, Berry E, Cavert W, Kinzel N, Lawrence DM, Hazra R, Major EO. Evidence of human immunodeficiency virus type 1 infection of nestin-positive neural progenitors in archival pediatric brain tissue. J Neuro-Oncol. 2007;13: 274-83.

19. Curtis K, Rollins M, Carryl H, Bradshaw K, Van Rompay KK, Abel K, Burke MW. Reduction of pyramidal and immature hippocampal neurons in pediatric simian immunodeficiency virus infection. Neuroreport. 2014;25:973-8.

20. Krathwohl MD, Kaiser JL. HIV-1 promotes quiescence in human neural progenitor cells. J Infect Dis. 2004;190:216-26.

21. Thaney VE, Sanchez AB, Fields JA, Minassian A, Young JW, Maung R, Kaul M. Transgenic mice expressing HIV-1 envelope protein gp120 in the brain as an animal model in neuroAIDS research. J Neuro-Oncol. 2018;24:156-67.

22. Avraham HK, Jiang S, Fu Y, Rockenstein E, Makriyannis A, Wood J, Wang L, Masliah E, Avraham S. Impaired neurogenesis by HIV-1-Gp120 is rescued by 
genetic deletion of fatty acid amide hydrolase enzyme. $\mathrm{Br} J$ Pharmacol. 2015;172:4603-14.

23. Lee $M H$, Amin ND, Venkatesan A, Wang T, Tyagi R, Pant HC, Nath A. Impaired neurogenesis and neurite outgrowth in an HIV-gp120 transgenic model is reversed by exercise via BDNF production and Cdk5 regulation. J Neuro-Oncol. 2013;19:418-31.

24. Lee MH, Wang T, Jang MH, Steiner J, Haughey N, Ming GL, Song H, Nath A, Venkatesan A. Rescue of adult hippocampal neurogenesis in a mouse model of HIV neurologic disease. Neurobiol Dis. 2011;41:678-87.

25. Okamoto S, Kang YJ, Brechtel CW, Siviglia E, Russo R, Clemente A, Harrop A, McKercher S, Kaul M, Lipton SA. HIV/gp120 decreases adult neural progenitor cell proliferation via checkpoint kinase-mediated cell-cycle withdrawal and G1 arrest. Cell Stem Cell. 2007;1:230-6.

26. Langford D, Oh Kim B, Zou W, Fan Y, Rahimain P, Liu Y, He JJ. Doxycycline-inducible and astrocyte-specific HIV-1 Tat transgenic mice (iTat) as an HIV/neuroAIDS model. J Neuro-Oncol. 2018;24:168-79.

27. Fan Y, Gao X, Chen J, Liu Y, He JJ. HIV Tat impairs neurogenesis through functioning as a notch ligand and activation of notch signaling pathway. J Neurosci. 2016;36:11362-73.

28. Lawrence DM, Durham LC, Schwartz L, Seth P, Maric D, Major EO. Human immunodeficiency virus type 1 infection of human brain-derived progenitor cells. J Virol. 2004;78:7319-28.

29. Schwartz L, Major EO. Neural progenitors and HIV-1-associated central nervous system disease in adults and children. Curr HIV Res. 2006;4: 319-27.

30. Tran PB, Ren D, Miller RJ. The HIV-1 coat protein gp120 regulates CXCR4mediated signaling in neural progenitor cells. J Neuroimmunol. 2005;160: 68-76.

31. Balinang JM, Masvekar RR, Hauser KF, Knapp PE. Productive infection of human neural progenitor cells by R5 tropic HIV-1: opiate co-exposure heightens infectivity and functional vulnerability. AIDS. 2017;31:753-64.

32. Skowronska M, McDonald M, Velichkovska M, Leda AR, Park M, Toborek M. Methamphetamine increases HIV infectivity in neural progenitor cells. J Biol Chem. 2018;293:296-311.

33. Demir M, Laywell ED. Neurotoxic effects of AZT on developing and adult neurogenesis. Front Neurosci. 2015;9:93.

34. Jin J, Grimmig B, Izzo J, Brown LA, Hudson C, Smith AJ, Tan J, Bickford PC, Giunta B. HIV non-nucleoside reverse transcriptase inhibitor efavirenz reduces neural stem cell proliferation in vitro and in vivo. Cell Transplant. 2016;25:1967-77.

35. Xu P, Wang Y, Qin Z, Qiu L, Zhang M, Huang Y, Zheng JC. Combined medication of antiretroviral drugs tenofovir disoproxil fumarate, emtricitabine, and raltegravir reduces neural progenitor cell proliferation in vivo and in vitro. J Neuroimmune Pharmacol. 2017;12:682-92.

36. Dickie P, Felser J, Eckhaus M, Bryant J, Silver J, Marinos N, Notkins AL. HIVassociated nephropathy in transgenic mice expressing HIV-1 genes. Virology. 1991;185:109-19.

37. Kopp JB, Klotman ME, Adler SH, Bruggeman LA, Dickie P, Marinos NJ, Eckhaus M, Bryant JL, Notkins AL, Klotman PE. Progressive glomerulosclerosis and enhanced renal accumulation of basement membrane components in mice transgenic for human immunodeficiency virus type 1 genes. Proc Natl Acad Sci U S A. 1992:89:1577-81.

38. Carroll VA, Lafferty MK, Marchionni L, Bryant JL, Gallo RC, Garzino-Demo A. Expression of HIV-1 matrix protein p17 and association with B-cell lymphoma in HIV-1 transgenic mice. Proc Natl Acad Sci U S A. 2016;113: 13168-73.

39. Lu TC, He JC, Klotman P. Animal models of HIV-associated nephropathy. Curr Opin Nephrol Hypertens. 2006;15:233-7.

40. Gharavi AG, Ahmad T, Wong RD, Hooshyar R, Vaughn J, Oller S, Frankel RZ, Bruggeman LA, D'Agati VD, Klotman PE, Lifton RP. Mapping a locus for susceptibility to HIV-1-associated nephropathy to mouse chromosome 3. Proc Natl Acad Sci U S A. 2004;101:2488-93.

41. Mallipattu SK, Liu R, Zhong Y, Chen EY, D'Agati V, Kaufman L, Ma'ayan A, Klotman PE, Chuang PY, He JC. Expression of HIV transgene aggravates kidney injury in diabetic mice. Kidney Int. 2013;83:626-34.

42. Zhong J, Zuo Y, Ma J, Fogo AB, Jolicoeur P, Ichikawa I, Matsusaka T. Expression of HIV-1 genes in podocytes alone can lead to the full spectrum of HIV-1associated nephropathy. Kidney Int. 2005;68:1048-60.

43. Ocwieja KE, Sherrill-Mix S, Mukherjee R, Custers-Allen R, David P, Brown M, Wang S, Link DR, Olson J, Travers K, et al. Dynamic regulation of HIV-1
mRNA populations analyzed by single-molecule enrichment and long-read sequencing. Nucleic Acids Res. 2012;40:10345-55.

44. Yin C, Zhang T, Qu X, Zhang Y, Putatunda R, Xiao X, Li F, Xiao W, Zhao H, Dai S, et al. In vivo excision of HIV-1 provirus by saCas9 and multiplex single-guide RNAs in animal models. Mol Ther. 2017;25: $1168-86$.

45. Zhang Y, Liu J, Yao S, Li F, Xin L, Lai M, Bracchi-Ricard V, Xu H, Yen $W$, Meng $W$, et al. Nuclear factor kappa B signaling initiates early differentiation of neural stem cells. Stem Cells. 2012;30:510-24.

46. Beckervordersandforth R, Ebert B, Schaffner I, Moss J, Fiebig C, Shin J, Moore DL, Ghosh L, Trinchero MF, Stockburger C, et al. Role of mitochondrial metabolism in the control of early lineage progression and aging phenotypes in adult hippocampal neurogenesis. Neuron. 2017;93:560-73 e566.

47. von Bohlen Und Halbach O. Immunohistological markers for staging neurogenesis in adult hippocampus. Cell Tissue Res. 2007;329:409-20,

48. Azari H, Rahman M, Sharififar S, Reynolds BA. Isolation and expansion of the adult mouse neural stem cells using the neurosphere assay. J Vis Exp. 2010; 45:2393.

49. Ostenfeld T, Svendsen CN. Requirement for neurogenesis to proceed through the division of neuronal progenitors following differentiation of epidermal growth factor and fibroblast growth factor-2-responsive human neural stem cells. Stem Cells. 2004;22:798-811.

50. Ge S, Goh EL, Sailor KA, Kitabatake Y, Ming GL, Song H. GABA regulates synaptic integration of newly generated neurons in the adult brain. Nature. 2006:439:589-93.

51. van Praag H, Schinder AF, Christie BR, Toni N, Palmer TD, Gage FH. Functional neurogenesis in the adult hippocampus. Nature. 2002;415: $1030-4$.

52. Festa L, Gutoskey CJ, Graziano A, Waterhouse BD, Meucci O. Induction of interleukin-1 beta by human immunodeficiency virus-1 viral proteins leads to increased levels of neuronal ferritin heavy chain, synaptic injury, and deficits in flexible attention. J Neurosci. 2015;35:10550-61.

53. Dickstein DL, Dickstein DR, Janssen WG, Hof PR, Glaser JR, Rodriguez A, O'Connor N, Angstman P, Tappan SJ. Automatic dendritic spine quantification from confocal data with Neurolucida 360. Curr Protoc Neurosci. 2016;77:1.27.1-1.27.21.

54. Peng J, Vigorito M, Liu X, Zhou D, Wu X, Chang SL. The HIV-1 transgenic rat as a model for HIV-1 infected individuals on HAART. J Neuroimmunol. 2010; 218:94-101.

55. Siebzehnrubl FA, Vedam-Mai V, Azari H, Reynolds BA, Deleyrolle LP. Isolation and characterization of adult neural stem cells. Methods Mol Biol. 2011;750:61-77.

56. Fitting S, Knapp PE, Zou S, Marks WD, Bowers MS, Akbarali HI, Hauser KF. Interactive HIV-1 Tat and morphine-induced synaptodendritic injury is triggered through focal disruptions in $\mathrm{Na}(+)$ influx, mitochondrial instability, and $\mathrm{Ca}(2)(+)$ overload. J Neurosci. 2014;34:12850-64.

57. Masliah E, Heaton RK, Marcotte TD, Ellis RJ, Wiley CA, Mallory M, Achim CL, McCutchan JA, Nelson JA, Atkinson JH, Grant I. Dendritic injury is a pathological substrate for human immunodeficiency virusrelated cognitive disorders. HNRC Group. The HIV Neurobehavioral Research Center. Ann Neurol. 1997;42:963-72.

58. Johnson TP, Patel K, Johnson KR, Maric D, Calabresi PA, Hasbun R, Nath A. Induction of IL-17 and nonclassical T-cell activation by HIVTat protein. Proc Natl Acad Sci U S A. 2013;110:13588-93.

59. Bruggeman LA, Thomson MM, Nelson PJ, Kopp JB, Rappaport J, Klotman PE, Klotman ME. Patterns of HIV-1 mRNA expression in transgenic mice are tissue-dependent. Virology. 1994;202:940-8.

60. Rahimian P, He JJ. HIV-1 Tat-shortened neurite outgrowth through regulation of microRNA-132 and its target gene expression. J Neuroinflammation. 2016;13:247.

61. Fields J, Dumaop W, Eleuteri S, Campos S, Serger E, Trejo M, Kosberg K, Adame A, Spencer B, Rockenstein E, et al. HIV-1 Tat alters neuronal autophagy by modulating autophagosome fusion to the Iysosome: implications for HIV-associated neurocognitive disorders. J Neurosci. 2015;35:1921-38.

62. Zhou BY, Liu Y, Kim B, Xiao Y, He JJ. Astrocyte activation and dysfunction and neuron death by HIV-1 Tat expression in astrocytes. Mol Cell Neurosci. 2004;27:296-305.

63. Vasquez JJ, Hussien R, Aguilar-Rodriguez B, Junger H, Dobi D, Henrich TJ, Thanh C, Gibson E, Hogan LE, McCune J, et al. Elucidating the 
burden of HIV in tissues using multiplexed immunofluorescence and in situ hybridization: methods for the single-cell phenotypic characterization of cells harboring HIV in situ. J Histochem Cytochem. 2018:66:427-46.

64. Deleage C, Wietgrefe SW, Del Prete G, Morcock DR, Hao XP, Piatak M Jr, Bess J, Anderson JL, Perkey KE, Reilly C, et al. Defining HIV and SIV reservoirs in lymphoid tissues. Pathog Immun. 2016;1:68-106.

65. Zilionis R, Nainys J, Veres A, Savova V, Zemmour D, Klein AM, Mazutis L. Single-cell barcoding and sequencing using droplet microfluidics. Nat Protoc. 2017;12:44-73.

66. Cole C, Byrne A, Beaudin AE, Forsberg EC, Vollmers C. Tn5Prime, a Tn5 based 5' capture method for single cell RNA-seq. Nucleic Acids Res. 2018;46: 62.

67. lascone DM, Padidam S, Pyfer MS, Zhang X, Zhao L, Chin J. Impairments in neurogenesis are not tightly linked to depressive behavior in a transgenic mouse model of Alzheimer's disease. PLoS One. 2013;8:e79651.

68. Mu Y, Gage FH. Adult hippocampal neurogenesis and its role in Alzheimer's disease. Mol Neurodegener. 2011;6:85.

69. Carey AN, Sypek El, Singh HD, Kaufman MJ, McLaughlin JP. Expression of HIV-Tat protein is associated with learning and memory deficits in the mouse. Behav Brain Res. 2012;229:48-56.

70. Mishra M, Taneja M, Malik S, Khalique H, Seth P. Human immunodeficiency virus type 1 Tat modulates proliferation and differentiation of human neural precursor cells: implication in NeuroAIDS. J Neuro-Oncol. 2010;16:355-67.

71. Chao J, Yang L, Yao H, Buch S. Platelet-derived growth factor-BB restores HIV Tat -mediated impairment of neurogenesis: role of GSK-3beta/betacatenin. J Neurolmmune Pharmacol. 2014;9:259-68.

72. Azari H, Louis SA, Sharififar S, Vedam-Mai V, Reynolds BA. Neural-colony forming cell assay: an assay to discriminate bona fide neural stem cells from neural progenitor cells. J Vis Exp. 2011;49:2639.

73. Fatima M, Kumari R, Schwamborn JC, Mahadevan A, Shankar SK, Raja R, Seth P. Tripartite containing motif 32 modulates proliferation of human neural precursor cells in HIV-1 neurodegeneration. Cell Death Differ. 2016;23:776-86.

74. Hahn YK, Podhaizer EM, Hauser KF, Knapp PE. HIV-1 alters neural and glial progenitor cell dynamics in the central nervous system: coordinated response to opiates during maturation. Glia. 2012;60:1871-87.

75. Yao H, Duan M, Yang L, Buch S. Platelet-derived growth factor-BB restores human immunodeficiency virus Tat-cocaine-mediated impairment of neurogenesis: role of TRPC1 channels. J Neurosci. 2012;32:9835-47.

76. Das S, Basu A. Viral infection and neural stem/progenitor cell's fate: implications in brain development and neurological disorders. Neurochem Int. 2011;59:357-66.

77. Yang L, Chen X, Hu G, Cai Y, Liao K, Buch S. Mechanisms of platelet-derived growth factor-BB in restoring HIV Tat-cocaine-mediated impairment of neuronal differentiation. Mol Neurobiol. 2016;53:6377-87.

78. Peng H, Sun L, Jia B, Lan X, Zhu B, Wu Y, Zheng J. HIV-1-infected and immuneactivated macrophages induce astrocytic differentiation of human cortical neural progenitor cells via the STAT3 pathway. PLoS One. 2011;6:e19439.

79. Avraham HK, Jiang S, Fu Y, Rockenstein E, Makriyannis A, Zvonok A, Masliah E, Avraham S. The cannabinoid CB(2) receptor agonist AM1241 enhances neurogenesis in GFAP/Gp120 transgenic mice displaying deficits in neurogenesis. Br J Pharmacol. 2014;171:468-79.

80. Connor Rl, Sheridan KE, Ceradini D, Choe S, Landau NR. Change in coreceptor use correlates with disease progression in HIV-1-infected individuals. J Exp Med. 1997;185:621-8.

81. Scarlatti G, Tresoldi E, Bjorndal A, Fredriksson R, Colognesi C, Deng HK, Malnati MS, Plebani A, Siccardi AG, Littman DR, et al. In vivo evolution of HIV-1 co-receptor usage and sensitivity to chemokine-mediated suppression. Nat Med. 1997;3:1259-65.

Ready to submit your research? Choose BMC and benefit from:

- fast, convenient online submission

- thorough peer review by experienced researchers in your field

- rapid publication on acceptance

- support for research data, including large and complex data types

- gold Open Access which fosters wider collaboration and increased citations

- maximum visibility for your research: over $100 \mathrm{M}$ website views per year

At BMC, research is always in progress.

Learn more biomedcentral.com/submissions 